\title{
Study of the inhibitory effect of Ethanolic extract of( Quercus robur,Cinnamomum zeylanicum and Thymus vulgaris ) on the growth of Staphylococcus aureus isolated from clinical mastitis in cow
}

\author{
Z. A. Hatem \\ J. A. Sabeeh \\ Coll. of Vet. Med. /Unive. of Al- Qadisiyia
}

\begin{abstract}
The present study was designed to evaluate the inhibitory effects of three local plant ethanolic extracts (Quercus robur, Cinnamomum zeylanicum and Thymus vulgaris) against the growth of Staphylococcus aureus isolated from milk of cow infected with clinical mastits in culture media by using of agar well diffusion method. For this purpose graduate concentrates for each extract $(50,100,200,400) \mathrm{mg} / \mathrm{ml}$ prepared and tested .The result showed that the extract of Quercus robur was more effective followed by Thymus vulgaris and Cinnamomum zeylanicum. The statistical analysis by using ANOVA with LSD at level $(\mathrm{p}<0.05)$ showed that there was no significant differences between the effect of the studied concentrations of Quercus robur, Cinnamomum zeylanicum while for Thymus vulgaris we find that the concentration 100 mg $\backslash \mathrm{ml}$ had a significant difference with the other studied concentration in inhibition of the growth of the tested bacteria. We also find that between the antibiotics the largest zone of inhibition was given by LOM followed by SPV,PI,NV,RA and CX.
\end{abstract}

\section{Introduction}

Medicinal plants are a source of great economic value all over the world. Nature has bestowed on us a very rich botanical wealth and a large number of diverse types of plants grow in different parts of the country (1).Nowadays multiple drug resistance has developed due to the indiscriminate use of commercial antimicrobial drugs commonly used in the treatment of infectious disease. In addition to this problem, antibiotics are sometimes associated with adverse effects on the host including hypersensitivity, immunesuppression and allergic reactions. This situation forced scientists to search for new antimicrobial substances. Given the alarming incidence of antibiotic resistance in bacteria of medical importance, there is a constant need for new and effective therapeutic agents. Therefore, there is a need to develop alternative antimicrobial drugs for the treatment of infectious diseases from medicinal plants (2). Antimicrobials of plant origin have enormous therapeutic potential. They are effective in the treatment of infectious diseases while simultaneously mitigating many of the side effects that are often associated with synthetic antimicrobials. The beneficial medicinal effects of plant materials typically result from the combinations of secondary products present in the plant. In plants, these compounds are mostly secondary metabolites such as alkaloids, steroids, tannins, and phenol compounds, flavonoids , steroids, resins fatty acids gums which are capable of producing definite physiological action on body $(3,4)$. Worldwide, economic losses due to mastitis have been estimated at $\$ 35$ billion (5). Staphylococcus spp. is the main causative agent of bovine mastitis, with higher prevalence in cases of clinical and subclinical manifestations (6). The most common treatment is based on intramammary infusion of antibacterial agents. However, cure rates obtained with 


\section{$\begin{array}{llll}\text { AL-Qadisiya Journal of Vet.Med.Sci. } & \text { Vol./12 } & \text { No./1 }\end{array}$}

such drugs are not always effective, because it may determine the emergence of resistant bacteria (7) as well increase amounts of antibiotic residues in milk (6). Nevertheless, the treatment of bovine subclinical mastitis caused by $S$. aureus in the lactation can be economically unviable (7). In this context, this study aimed to: a) evaluate the in vitro antimicrobial activity of ethanolic extract of

\section{Materials and Methods}

\section{1- Plant collection and preparation :}

In this experiments we used three local medicinal plants include: Quercus robur, Cinnamomum zeylanicum and Thymus vulgaris. All these plants were obtained from the local market and identified by the national Iraqi institute for herbs, we take the fruits of the first plant, stem of the second plant and fruits of the third plant, then all the chosen parts of the above plants were subjected to aerial drying for two weeks, after drying of these parts we grinded it very well until it became as a fine powder . The Ethanolic extraction of the three plants were done by Harborn method (8) by using of Ethanol at a concentration (96\%).

2- Staphylococcus aureus Isolates: A-Sample collection :

Milk samples were collected in sterile tubes (2 tubes) for each sample one for California mastitis test (CMT) and another for bacteriological test) and a septic technique used for milk samples collection according to (9) .

\section{B-Bacterial culture and identification:}

All milk samples from subclinical mastitis cases which gave a positive reaction with ( CMT) were submitted to centrifugation at $3000 \mathrm{rpm} / 15$ minute, and the precipitate was cultured on :Blood Agar, Nutrient Agar and MacConky Agar, all the Petri plate that contain this agars were incubated at $37 \mathrm{C}^{\circ}$ for 24 - 48hrs .Diagnosis depend on morphological character \& cultural character, then followed by examination with gram stain, after that the colonies were subcultured on selective media and
(Quercus robur, Cinnamomum zeylanicum and Thymus vulgaris ) against Staphylococcus spp; b) compare the activity of these extracts against Staphylococcus spp. isolate with multiple profiles of susceptibility and resistance to (Lomefloxacin, Sparfloxacin,Novobiocin, , Pipemidic acid,, Rifampin, Cloxacillin) antibiotics.

differential media according to the type of isolated bacteria then incubated at $37 \mathrm{C}^{\circ}$ for $24-48 \mathrm{hrs}$. The biochemical test used to diagnosis of staphylococcus spp. were include:

- Catalase Test, Oxidase test, Coagulase Test, Urease Test, Heamolysis on blood agar, Gelatin Liquefaction Test ( Gelatinase ) , Voges - Proskauer Test , Nitrate reduction Test, Sugar Fermentation Test ( Mannitol , Lactose , Mannose , Xylose ,Trehalose, Sucrose , Maltose ) according to the method of $(9,10,11)$.

Production of pigment in Mannitol salt agar and in ( Staph 110 media) (LAB -U.K)

MAST STAPHTM: ( Mast Group Ltd , USA) API Staph ( biomerioux, France).

\section{3- Antibiotics}

In this study we use (6) antibiotics to compare their antibacterial effect with that of the medicinal plants ethanolic extracts due to their broad spectrum activity and these antibiotics include: Lomefloxacin( LOM) $10 \mathrm{mcg}$,Sparfloxacin (SPX) $5 \mathrm{mcg}$ ,Novobiocin (NV) $30 \mathrm{mcg}$,Pipemidic acid (PI) $20 \mathrm{mcg}$, Rifampin(RA) $5 \mathrm{mcg}$, Cloxacillin (CX) .(Bioanalyse $)^{\circledR}$.

\section{4- Serial dilutions :}

For each of the tested medicinal plants we had been made a serial dilution to study the effect of the plants in inhibition the growth of Staphylococcus spp. at a different concentrations and select the most effective concentration of the plant extract depending on the zone of inhibition of growth that been given by each concentration, we started with a concentration (400) $\mathrm{mg} / \mathrm{ml}$ (prepared by add $10 \mathrm{ml}$ from Ethanol $96 \%$ to $4 \mathrm{gm}$ of 
the plant extract) and the second concentration is $200 \mathrm{mg} / \mathrm{ml}$ ( prepared by taking $4 \mathrm{ml}$ from the first dilution and we add $4 \mathrm{ml}$ of ethanol $96 \%$ to it ,the third dilution is $100 \mathrm{mg} / \mathrm{ml}$ (prepared by taking $2 \mathrm{ml}$ from the second dilution and add $2 \mathrm{ml}$ of ethanol $96 \%$ to it) ,the fourth dilution is $50 \%$ ( made by taking $2 \mathrm{ml}$ from the third dilution and add $2 \mathrm{ml}$ of ethanol $96 \%$ to it). These serial dilution was decided depending on clinical trails.

\section{5-Senstivity test study:}

After preparation of all the medicinal plants ethanolic extracts and activation of the pathogenic bacteria in the nutrient broth , the Mueller Hinton Agar ( HIMEDIA -MumbaiIndia) was prepared by dissolve $38 \mathrm{gm}$ from the agar powder in $1000 \mathrm{ml}$ of distilled water in a flask and shaking it well to dissolve the agar and then we start heating it by a Benzen burner in attempt to complete dissolving of all the agar powder and after that the agar was sterilize by using of autoclave at 15 IP for 15 minutes . After preparation of Mueller Hinton agar we poured it in to Petri plates and after solidification of the agar we made

\section{Results and discussion}

Mastitis in cattle is caused primarily by bacteria that invade the udder, multiply, and produce toxins that are harmful to the mammary gland (13). A part from causing colossal economic losses, mastitis also posses the risk for the transmission of zoonotic diseases like tuberculosis, brucellosis, leptospirosis and streptococcal sore throat to human beings (14). It can be associated with health risks to consumers, especially those related to the presence of zoonotic pathogens and antimicrobial drug residues in milk (15). Staph.aureus is considered one of the major pathogens that cause clinical mastitis( 16), . In our study we try to experiment the effect of selected medicinal plants in comparison to Antibiotics on Staphylococcus aureus isolated from milk of cow infected with clinical mastitis growing invitro in a Muller Hinton Agar by using of agar well diffusion
4 wells ( $5 \mathrm{~mm}$ diameter) in each one of the Petri plates except those of the antibiotics discs , 13 Petri plates containing Mueller Hinton agar were used in this study $\{(9$ plates for the medicinal plant extract study :3 plates for each extract) and (4 Petri plates for antibiotics: 2 plates for each four antibiotics)\}. This study was done by taking swap from the test tube that contain the bacterial suspension and inoculated it on the Petri plates that contain the Mueller Hinton agar, and then we added $0.1 \mathrm{ml}$ of each concentration of each plant extract on its own plates and we applied the chosen antibiotics discs in it is plates.After complete applying of all the medicinal plants extracts concentrations and the Antibiotics we incubated all the Petri plates at $37^{\circ}$ for 24 hours .The sensitivity of microorganisms towards the plants extracts was screened by following the agar well -diffusion method .The zone of inhibition (diameter in $\mathrm{mm}$ ) in triplicates was measured and the mean value ( $\mu$ ) was tabulated (12).

method.Agar -based methods are attractive because of their simplicity and low cost ,in addition to that it may help to detect if there any resistance from the yeast or the bacteria to any drug, medicinal plants or agents that may be used to study it is effect(17), The antibacterial activity of Oak(Quercus robur), Cinnamon(Cinnamomum zeylanicum) and Thyme (Thymus vulgaris) extracts were tested against Staphylococcus aureus invitro and the results are listed in (Table 1),(Fig. 1). It was found that ethanolic extract of Oak was the most effective antibacterial with a zone of inhibition as followed according to the studied concentrations $(400,200,100,50 \mathrm{mg} \backslash \mathrm{ml})$ ( $33.555 \pm 0.929$, $29.0 \pm 0.333, \quad 29.222 \pm 0.222, \quad 30.555 \pm 1.986)$ $\mathrm{mg} \backslash \mathrm{ml}$ respectively (Fig. 2), followed by the effect of ethanolic extract of Thyme which gave a zone of inhibition according to the 
studied concentrations $(24.111 \pm 0.351$, $25.333 \pm 0.6, \quad 28.777 \pm 0.64, \quad 20.556 \pm 1.684)$ $\mathrm{mg} \backslash \mathrm{ml}$ respectively (Fig.4), then followed by the inhibition zones gave by Cinnamon $(25.333 \pm 0.288, \quad 25.444 \pm 0.242, \quad 24.0 \pm 0.5$, $18.666 \pm 0.2350 \mathrm{mgl}, \mathrm{ml}$ respectively(Fig.3) . The antibiotics used in this study also showed an inhibition to the growth of $S$. aureus invitro with an inhibition zones as follow: (LOM 29.44 \pm 0.41, SPX 21.55 \pm 0.44 , PI $20.66 \pm 0.37$, NV19 \pm 0.4, RA $11.11 \pm 0.26$, CX 0 \pm 0 ) table (2). The result showed that there were no significant differences $(\mathrm{P}<$ 0.05 ) between the result obtained by the different concentrations that had been used for each of Oak and Cinnamon while there was a significant differences $(\mathrm{P}<0.05)$ between the concentrations $(400,200,50$ $\mathrm{mg} \backslash \mathrm{ml})$ and $100 \mathrm{mg} \backslash \mathrm{ml}$ of Thyme .The major antimicrobial components of the medicinal plants in the study include Tannins and Quercetin for Oak ,also Tannins and Cinnamaldehyde for Cinnamon that had been reported to have an inhibition effect to the growth of S.aureus( 18) and for Thyme it contain Caffeic acid ,tannins and thymol (19) , tannins can be toxic to filamentous fungi, yeasts, and bacteria. Condensed tannins have been determined to bind cell walls of ruminal bacteria, preventing growth and protease activity (20).S. aureus (grampositive) being more susceptible to plant tannin extracts $(21,22)$, and the mechanisms of action in the growth inhibition of bacteria are involved, such as destabilization of cytoplasmic and plasma membranes, inhibition of extracellular microbial enzymes and metabolisms, and deprivation of the substrate required for microbial growth $(22 ; 23 ; 24)$. The site (s) and number of hydroxyl (-OH) groups on the tannins are also thought to be related to their relative toxicity to microorganisms, with increased hydroxylation resulting in increased toxicity $(25,26)$. The medicinal plants like Cinnamon are being used traditionally for the treatment of inflammation, cough, toothache, antiseptics expectorant, and some fungal infection like candidaisis. The ethanol extracts of Cinnamon showed notable antibacterial activity against Gram positive bacteria(27).The antibacterial activity has been attributed to the presence of some active constituents in the extracts. Studies suggested that the antibacterial ctivity of Cinnamon was probably due to their major component, cinnamaldehyde and their properties could be multiple. An important characteristic of plant extracts and their components is their hydrophobicity, which enable them to partition the lipids of the bacterial cell membrane and mitochondria, disturbing the cell structures and rendering them more permeable. Extensive leakage from bacterial cells or the exit of critical molecules and ions will lead to death.(28).The ethanolic extract of Thyme contains many phytochemicals substances including terpenoids, tannins and polyphenolic compounds as well as flavonoids. The different components diffusing at different rates may have been responsible for the varying zones of inhibition obtained in against the susceptible microorganisms. This plant is assumed to have compounds which have a potential antimicrobial activity its important compounds are flavonoids. Flavonoid's activity is probably due to their ability to complex with extra cellular and soluble proteins and to complex with bacterial cell walls and lipophilic flavonoids may also disrupt bacterial membranes. If the components could be separated and tested further we might find use as individual antibacterial agent against Gram-positive infections (29). The result showed that the inhibition zones produced by Oak was ranged between $(29.22-30.55) \mathrm{mm}$ which is close to the result of (30)how showed in his study that Oak gave an inhibition zone ranged from $(15-23 \mathrm{~mm})$ according to the studied concentrations, also the result produced by Thyme was ranged between 

AL-Qadisiya Journal of Vet.Med.Sci.
Vol./12
No./1
2013

(20.55-28.77) $\mathrm{mm}$ which was closed to the results of( 31) how tested the effect of Thymus daenensis on a number of bacteria include S.aureus and gave an inhibition zone ranged between $(19-20) \mathrm{mm}$ in studied concentration it was also agree with the results of $(32,33,34,35,36)$ advanced studies used Thymus spp. extracts as antimicrobial agents depend on presence of both thyme essential oil and thymol. Also, these studies suggested use of thyme as an antibiotic. the result of Cinnamon which was gave a zone of inhibition of the growth of the tested bacteria ranged from (18.66-25.44) $\mathrm{mm}$ also agree with the result of (37) who used Cinnamomum Zeylanicum effect against S.aureus and the inhibiton zone was about $10 \mathrm{~mm}$ for the minimal bactericidal concentration $10 \mathrm{mg} \backslash \mathrm{ml}$ which indicated that increasing the concentration of the plant extract will lead to increase the inhibition zone as indicated by our study, our result for Cinnamon was also close to the result of (38) who found that the ethanolic extract of Cinnamon was active against Staphylococcus aureus strains with zones of inhibition ranging from (10.0 - 11.4 )mm.As a conclusion we find in our study that each of the used medicinal plants ethanolic extracts ( Oak, Cinnamon and thyme) had antibacterial effect against S.aureus isolated from milk of cows infected with clinical mastitis with a significant differences between their effect $(\mathrm{P}<0.05)$ while there was no clear effect to the studied concentration of the used medicinal plants extract on it is inhibition effect on the tested bacteria except for Thyme that showed significant differences $(\mathrm{P}<0.05)$ between the inhibition effect of the studied concentrations of the plant on the tested bacteria.

Table (1): The antibacterial activity of the ethanolic extract of (Quercus robur, Cinnamum vulgaris, Thymus vulgaris) on S.aureus

\begin{tabular}{|c|l|l|l|l|}
\hline \multirow{2}{*}{ Plants extract } & \multicolumn{4}{|c|}{ Concentrations(mg\ml $)$} \\
\cline { 2 - 5 } & \multicolumn{1}{|c|}{400} & \multicolumn{1}{|c|}{200} & \multicolumn{1}{c|}{100} & \multicolumn{1}{c|}{50} \\
\hline Quercus robur & $\begin{array}{l}33.555 \pm 0.929 \\
\mathrm{aA}\end{array}$ & $\begin{array}{l}29.0 \pm 0.333 \\
\mathrm{bA}\end{array}$ & $\begin{array}{l}29.222 \pm 0.222 \\
\mathrm{cA}\end{array}$ & $\begin{array}{l}30.555 \pm 1.986 \\
\mathrm{dA}\end{array}$ \\
\hline $\begin{array}{c}\text { Cinnamum } \\
\text { vulgaris }\end{array}$ & $\begin{array}{l}25.333 \pm 0.288 \\
\mathrm{aB}\end{array}$ & $\begin{array}{l}25.444 \pm 0.242 \\
\mathrm{bB}\end{array}$ & $\begin{array}{l}24.0 \pm 0.5 \\
\mathrm{cB}\end{array}$ & $\begin{array}{l}18.666 \pm 0.235 \\
\mathrm{~dB}\end{array}$ \\
\hline $\begin{array}{c}\text { Thymus } \\
\text { vulgaris }\end{array}$ & $\begin{array}{l}24.111 \pm 0.351 \\
\mathrm{aC}\end{array}$ & $\begin{array}{l}25.333 \pm 0.6 \\
\mathrm{bC}\end{array}$ & $\begin{array}{l}28.777 \pm 0.64 \\
\mathrm{cB}\end{array}$ & $\begin{array}{l}20.556 \pm 1.684 \\
\mathrm{dC}\end{array}$ \\
\hline
\end{tabular}

*Values were expressed as means \pm standard error

*Values with different capital letters are significant differences vertically at $(\mathrm{p}<0.05)$.

*Values with different small letters are significant differences horizontally at $(\mathrm{p}$

Table (2): The antibiotic effect against S.aureus

\begin{tabular}{|c|c|}
\hline Antibiotics & Inhibition zone $(\mathrm{mm})$ \\
\hline LOM & $29.44 \pm 0.41$ \\
\hline SPX & $21.55 \pm 0.44$ \\
\hline PI & $20.66 \pm 0.37$ \\
\hline NV & $19 \pm 0.4$ \\
\hline RA & $11.11 \pm 0.26$ \\
\hline CX & $0 \pm 0$ \\
\hline
\end{tabular}


$\begin{array}{llll}\text { AL-Qadisiya Journal of Vet.Med.Sci. } \quad \text { Vol./12 } & \text { No./1 }\end{array}$

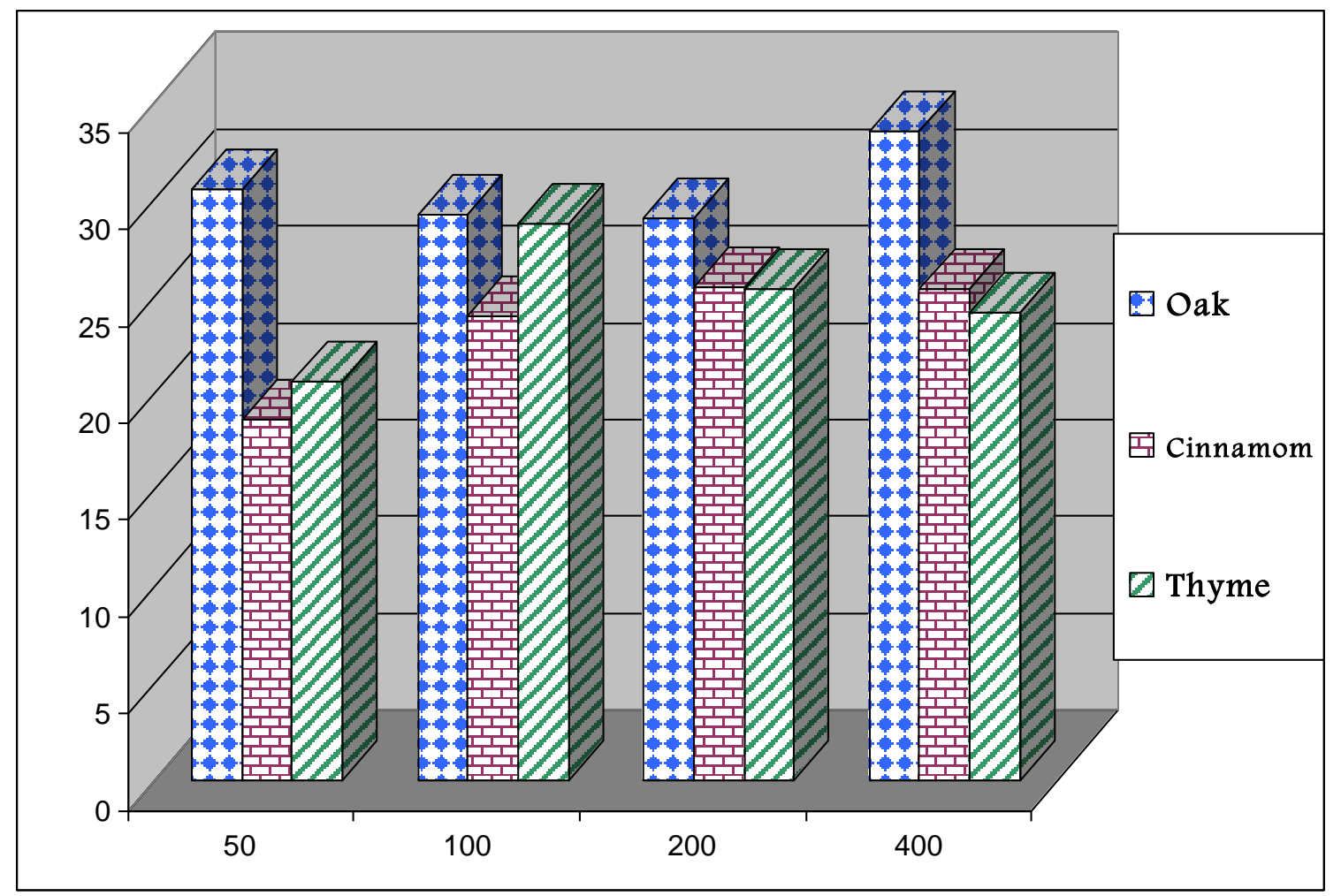

Figure (1): Inhibition zones of Staphylococcus aureus exhibited by the ethanolic extracts of the tested plants.

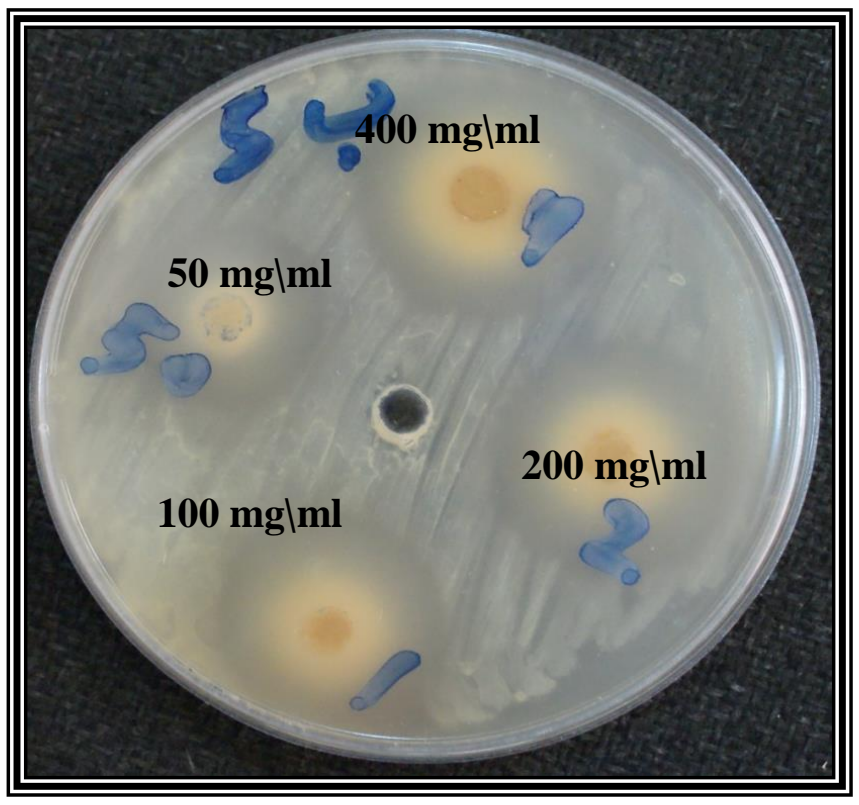

Figure (2): Inhibition zones of Staphylococcus aureus growth on Mueller-Hinton agar produced by ethanolic extract of Quercus rubur, the peripheral four wells contained extract concentrations ( 50, 100, $200,400 \mathrm{mg} / \mathrm{ml}$ ) where as the central well contained $0.1 \mathrm{ml}$ of $96 \%$ ethanol. 
AL-Qadisiya Journal of Vet.Med.Sci. $\quad$ Vol./12 No./1 2013

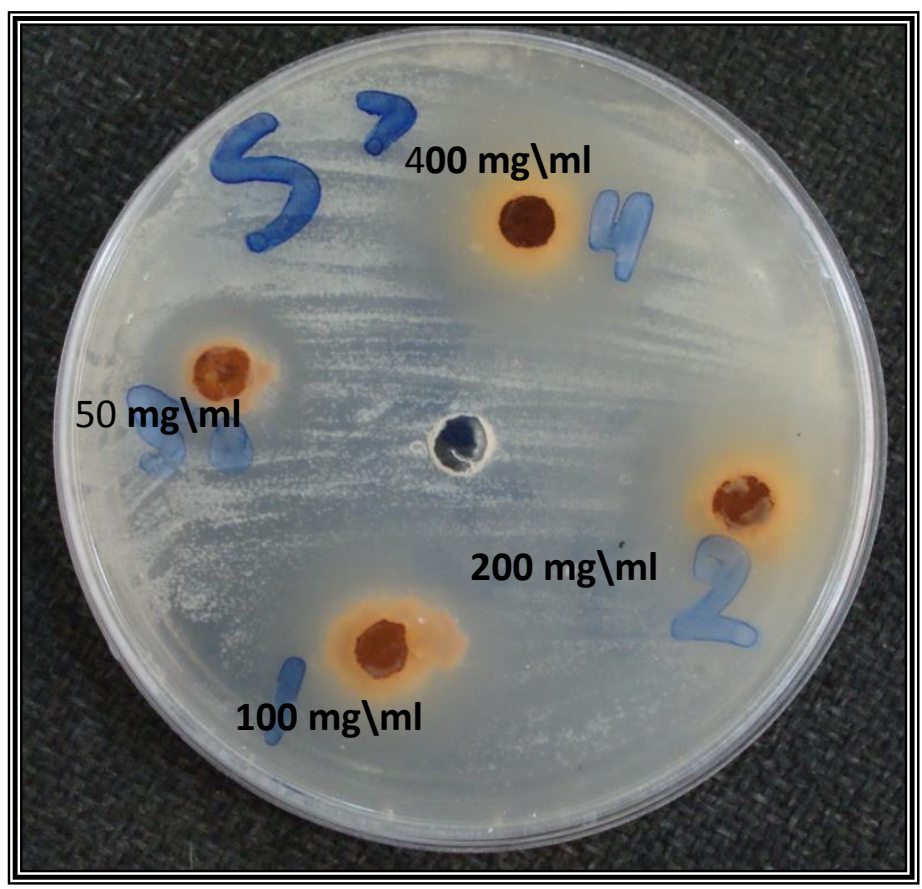

Figure (3): Inhibition zones of Staphylococcus aureus growth on Mueller-Hinton agar produced by ethanolic extract of Cinnamomum zeylanicum, the peripheral four wells contained extract concentrations $(50,100,200,400 \mathrm{mg} / \mathrm{ml})$ where as the central well contained $0.1 \mathrm{ml}$ of $96 \%$ ethanol .

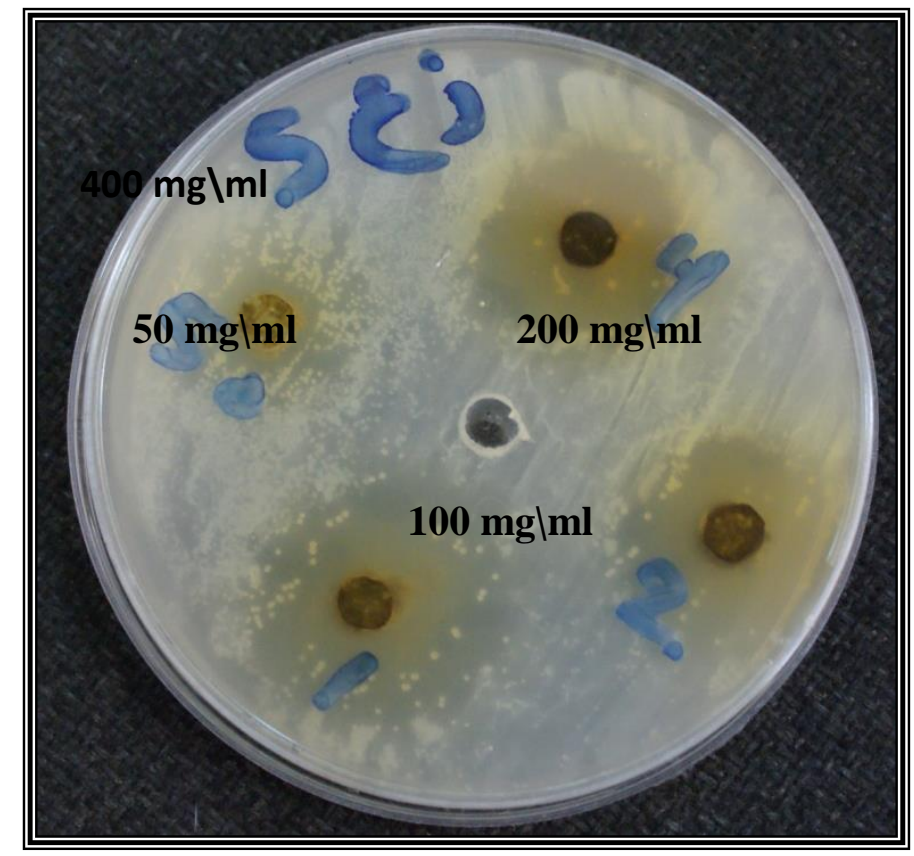

Figure (4): Inhibition zones of Staphylococcus aureus growth on Mueller-Hinton agar produced by ethanolic extract of Thymus vulgaris, the peripheral four wells contained extract concentrations $(50,100,200,400 \mathrm{mg} / \mathrm{ml})$ where as the central well contained $0.1 \mathrm{ml}$ of $96 \%$ ethanol . 
AL-Qadisiya Journal of Vet.Med.Sci. $\quad$ Vol./12 No./1 2013

1. Akerele, O.(1993).Summary of WHO Guidelines for the Assessment of Herbal Medicines Herbal Gram 22:13-28

2. Agrawal P, Rai V, Singh R, B.(1996). Randomized, placebo-controlled, single-blind trial of holy basil leaves in patients with noninsulindependent diabetes mellitus. International Journal of Clinical Pharmacology and Therapeutics. 34:406-409.

3. Joshi, A.R., Edington, J.M. 1990. The use of medicinal plants by two village communities in the Central Development Region of Nepal. Economic Botany. 44 (1):71-83.

4. Manandhar, N.P. (1987). Traditional medicinal plants used by tribals of Lamjung District, Nepal. International Journal of Crude Drug Research. 25 (4): 236-240.

5. Wellenberg, G.J.;Van der poel, W.H.; VAN oirschot, J.T.(2002): Viral infections and bovine mastitis: a review. Vet. Microbiol., (88), p.2745 ,.

6. Fagundes, H.; Barches, L.; Nader F.A. (2010):Occurrence of Staphylococcus aureus in raw milk produced in dairy farms in São Paulo State, Brazil. Braz. J. Microbiol., (41), p.376-380.

7. Zafalon, L.F.; Nader F., A.; Oliveria, J.V. (2007): Subclinical mastitis caused by Staphylococcus aureus: cost benefit analysis of antibiotic therapy in lactating cows. Arq. Bras. Med. Vet. Zootec., (59), p.577-585

8. Harborne J.B.;Mabray,T.J.;\&Mabaray ,H.(1975) .Physiology and function of flavonoid .p:970-1042.The flavoids .Acad.Press,New York,San Francisco.

9. Collee, J. G.; Fraser, A. G.; Marion , B. P. and Simmons, A. (eds)(1996).
Mackie and McCaraty Practical Medical Microbiology. $14^{\text {th }}$ ed. Longman Singapore.Pp:131-149.

10. Forbes , B.A.,Sahm,D.F., Weissfield ,A.S. (2002):Baily \&Scott s, Diag. Microb.11Ed .Mosby.

11. Macfaddin, J.F. (2000):Biochemical test for identification of medical bacteria 3 Ed .William and Willkins, ,U.S.A.

12. Al-Mohana, A.; Mahdi, O. and Ali,H. (2008). Antibacterial activity of alcoholic extract of local propolis against Listeria monocytogens. J.Anbar.For Vet.Sci.1:61-67.

13. Hansen PJ, Soto P, Natzke RP.(2004). Mastitis and fertility in cattle possible involvement of inflammation or immune activation in embryonic

14. Radostits, O.M., D.C. Blood, C.C. Gay, K.W. Hinchiff and J.A.Handerson, ( 2000). Veterinary Medicine a textbook of the diseases of cattle ,horse, sheep ,pigs and goat. 9th Ed. W. B. Saunders Company, London, U.K

15. Jones ,G.M.(1999): On-farm tests for drug residues in milk. milk quality \& milking management. Dep. Dairy Sci., Virginia Tech.: 404-401.

16. Radostitis,O.M;Gay,C.C.;Hinchcliff,K. W.;\&Constable,P.D. (2007): Veterinary Medicine a textbook of the diseases of cattle ,horse, sheep ,pigs and goat, $10^{\text {th }}$ Edition . London : W.B. saunders company Limited.

17. Barry ,A.L., and Brown .S.D. (1996). Fluconazole disc diffusion procedure for determing susceptibility of Candida species . J.Clin.Microbial. 34:2154-2157.

18. Bowles, B. L., Sackitey, S. K., Williams, A. C.(1995):Inhibitory effects of flavor compounds on Staphylococcus

aureus, 
$\begin{array}{llll}\text { AL-Qadisiya Journal of Vet.Med.Sci. } & \text { Vol./12 } & \text { No./1 }\end{array}$

Staphylococcus aureus WRRC

B124. J. Food Safety., 15, pp:337347

19. Marjorie,M.C.(1999):Plants products as antimicrobial agents.Clinic.Microbiology Rev. P:564-582.

20. Jones, G. A., T. A. McAllister, A. D. Muir, and K. J. Cheng. (1994). Effects of sainfoin (Onobrychis viciifolia scop.) condensed tannins on growth and proteolysis by four strains of ruminal bacteria. Appl. Environ. Microbiol.60:1374-1378.

21. Foo LY, Yinrong L, Howell AB, Vorsa N (2000): A-type proamthocyanidin trimers from cranberry that inhibit adherence of uropathogenic Pfimbricated Escherichia coli. J. Nat. Prod. 63:1225-1228.

22. Puupponen-Pimia R, Nohynek L, Alakomi HL, Oksman-Caldentey KM(2004): Bioactive berry compounds- novel tools against human pathogens. Appl. Microbiol. Biotechnol. 67:8-18

23. Bell TA, John L, Smart WWG (1965). Pectinase and cellulose enzyme inhibitor from sericea and certain other plants. Botanical Gazette.126:40-45.

24. Ikigai H, Nakae T, Hara Y, Shimamura $\mathrm{T}$ (1993). Bactericidal catechins damage the lipid bilayer. Biochem. Biophysic Acta 1147:132-136.

25. Tang HR, Hancock RA, Covington AD (1992). Study on the composition and structure of commercial chestnut tanning agent. In: Hemingway RW, Laks PE (eds) Plant Polyphenols. New York: Plenum Press. pp. 221-243

26. Bhat TK., Singh B, Sharma OP (1998): Microbial degradation of tannins A current perspective. Biodegradation 9: 343-357.

27. Smith Palmer, A., Stewart, J., Fyee, L.(1998): Antimicrobial properties of plant essential oils and essences against five important food borne pathogens. Lett. Appl. Microbiol., 26, pp:118-122

28. Rastogi, R.P.; Mehrotra, B.N.( 2002):. Glossary of Indian Medicinal Plants. National Institute of science communication, New Delhi, India.

29. Vila R (2002). Flavonoids and further Polyphenols in the genus Thymus. In: Stahl- Biskup E, Saez F editors.Thyme, Tyler and Francis, London, pp.144-175.

30. Min, B. R.; Pinchak, W. E.; Merkel, R.; Walker, S.; Tomita, G. and Anderson, R. C.4.(2008): Comparative antimicrobial activity of tannin extracts from perennial plants on mastitis pathogensScientific Research and Essay ..3 (2). pp:066-073.

31. Faraz, M.; Marshid, P.; Hadimehr, G. and Shima,P.;.(2008): antibacterial activity of Thymus daenesis methanolic extract. Pak. J. Pharm. Sci.21(3.) pp:210-213.

32. Panizzi, L., Flamini, G., Cioni, P. L. and Morreli, I. (1993). Composition and antimicrobial properties of essential oils of four Mediterranean lamiacease. J. Ethnopharmacol., 39(3): 167-170.

33. Cosentino, S., Tuberoso, C. I., Pisano, B. Satta, M., Mascia, V. Arzedi, E. and Palmas, F. (1999). In vitro antimicrobiol activity and chemical composition of Sardiian Thymus essential oils. Lett. Appl. Microbiol., 29(2): 130-135.

34. Marino, M., Bersani, C. and Comi, G. (1999). Antimicrobiol activity of the essential oils of Thymus vulgaris L. measured using a bioimpedometric method. J. Food. Prot., 62(9): 1017-1023.

35. Dorman, H. J. and Deans, S. G. (2000). Antimicrobiol agents from plants: antibacterial activity of plants 
$\begin{array}{llll}\text { AL-Qadisiya Journal of Vet.Med.Sci. } & \text { Vol./12 } & \text { No./1 } & 2013\end{array}$

volatile oils. J. Appl. Microbiol., 88(2): 309-316.

36. Al-Saimary ,I.E.(2007): Efficiency of antibacterial agents extracted from Thymus vulgaris 1 . (lamiaceae). The Internet Journal of Nutrition and Wellness. 2007 Volume 4 (1).

37. Bishnu ,J. ;Sunil, L.; Anuja ,S.(2009): Antibacterial Property of Different Medicinal Plants: Ocimum sanctum,Cinnamomum zeylanicum, Xanthoxylum armatum and Origanum majorana. Kathmandu university j.sci. ,. 5(1 ). pp: 143150.

38. Hoque,M.M.; Bari,M.L.;.Juneja,V.K and Kawamoto, S. (2008): Antimicrobial activity of Cloves and Cinnamon extract against food born pathogens and spoilage bacteria, and inactivation of Listeria monocytogenes in ground chicken meat with their ssential oils. Rep. Natl. Food Res. Inst No . 72.P: 921

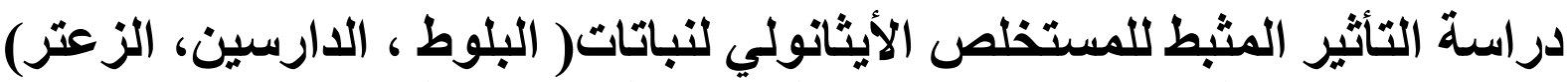

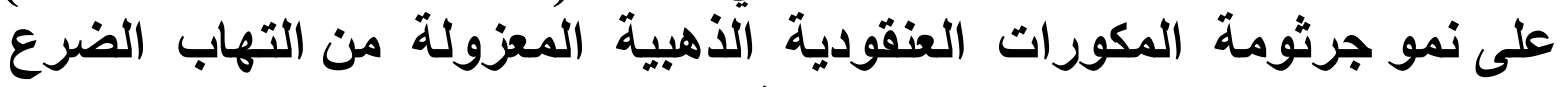 السريري في الابقار}

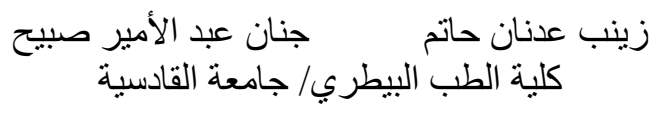

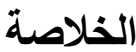

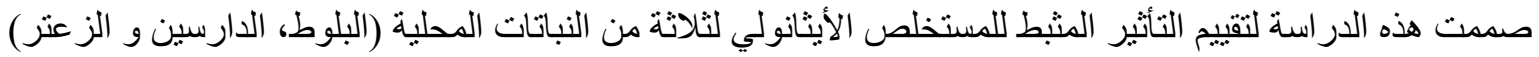

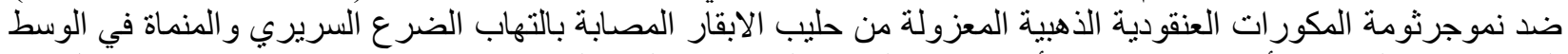

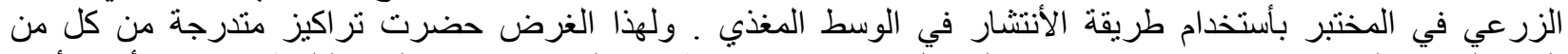

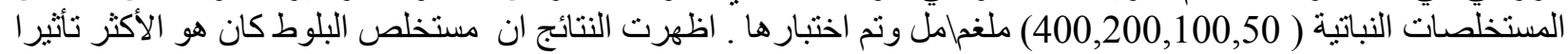

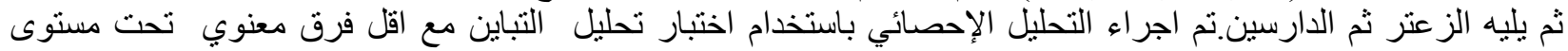

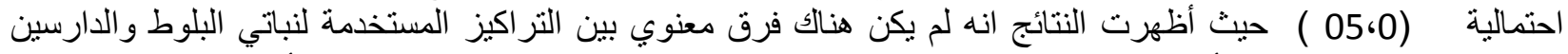

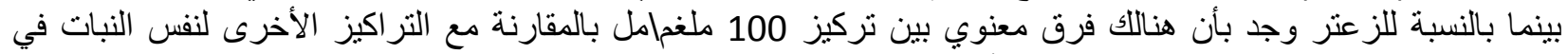

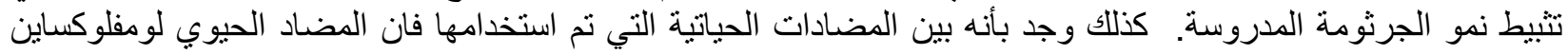
اعطى اكبر نطاق تثبيط لنمو البكتريا يليه سبارفلوكساسين ، نوفو بايوسين، بمبيديد التك اسيد ، ريفامبين وكلو كساسيلين . 